\title{
Formalised and Non-Formalised Methods in Resource Management-Knowledge and Social Learning in Participatory Processes: An Introduction
}

\author{
Jens Newig · Helmut Haberl · Claudia Pahl-Wostl · Dale S. Rothman
}

Published online: 4 February 2009

(C) Springer Science+Business Media, LLC 2009

\section{Erratum to: Syst Pract Action Res \\ DOI 10.1007/s11213-008-9112-x}

Please note that there were four Guest Editors for this special issue of the journal (not just one as indicated on the issue contents listing).

The Guest Editors for the issue are:

Jens Newig, Helmut Haberl, Claudia Pahl-Wostl, and Dale S. Rothman.

We apologize for this omission.

The online version of the original article can be found under doi:10.1007/s11213-008-9112-x.

J. Newig $(\square)$

Institute for Environmental and Sustainability Communication, Leuphana University,

Lüneburg, Germany

e-mail: newig@uni.leuphana.de

H. Haberl

Institute of Social Ecology, IFF Vienna, Klagenfurt University, Vienna, Austria

C. Pahl-Wostl

Institute of Environmental Systems Research, Osnabrück University, Osnabrück, Germany

D. S. Rothman

International Institute for Sustainable Development, Winnipeg, MB, Canada 